\title{
Islamic Banking: Inclusion in the Indian Banking Sector
}

\author{
*Dr.Shabana Mazhar \& **Dr. Nishi Tripathi. \\ * Assistant Professor (Sr. Scale) in Joseph School of Business Studies, SHIATS (Deemed-to-be-University), \\ Allahabad and **Associate Professor, Department of Psychology, SHIATS (Deemed-to-be-University),
} Allahabad

\begin{abstract}
Innumerable changes have been witnessed in the Indian banking sector since last six decades. Various generations of financial sector reforms has changed the face and complexion of the Indian Banking Sector which is adopting various innovative practices with the focus on inclusive growth. Islamic banking is one such practice which is being considered in full fledged manner which otherwise has been practiced in an informal way. Islamic banking has set its foot on the path of rapid growth throughout the globe and India could not be isolated from it, looking at immense potential. The 1st Ernst \& Young World Islamic Banking Competitiveness Report 2011 presented at the 18th Annual World Islamic Banking Conference stated that Islamic banking assets with commercial banks globally will reach US\$1.1 trillion in 2012, a significant jump of $33 \%$ from their 2010 level of US\$826 billion. The conventional banking as practiced by the Indian banking sector in its present form does stand in the way of the principles of Islamic banking which prohibits transaction on the basis of interest and operate on profit and loss based on Islamic principles. Introduction of interest free banking will require a lot of changes in the Banking Regulation Act.

Key Words: Interest free banking, Financial exclusion, Inclusive growth, Islamic financial institution,
\end{abstract}

\section{Introduction}

Innumerable changes have been witnessed in the Indian banking sector since last six decades. From nationalisation in the 60's to liberalisation in the 90 's this sector has been forging ahead as a significant element of the Indian Financial System. A well developed banking system is a pre-requisite for smooth and effective functioning of any economy. The basic function of the banking sector has been mobilising savings from the surplus entities and channelising them to deficit entities for productive purposes. These functions are based on the premise of interest rates, interest being given to depositor and interest being charged by the bank for lending. An alternate to this conventional banking system is Islamic banking which prohibits transaction on the basis of interest and operate on profit and loss based on Islamic principles. Islamic banking has set its foot on the path of rapid growth throughout the globe and India could not be isolated from it, looking at immense potential. The 1st Ernst \& Young World Islamic Banking Competitiveness Report 2011 presented at the 18th Annual World Islamic Banking Conference stated that Islamic banking assets with commercial banks globally will reach US\$1.1 trillion in 2012, a significant jump of 33\% from their 2010 level of US\$826 billion. Looking at the global recognition of Islamic Banking the RBI also weighed the option of introducing Islamic banking in the main stream of the Indian banking sector and constituted a committee in 2007 to examine the issues relating to Islamic banking. This can be the appropriate time for introduction of Islamic banking in India, when world is gripped under the impact of the subprime crisis, fallout of conventional banking based on interest and interest trap. Before discussing the convergence of Islamic banking into the mainstream banking sector it would be appropriate to highlight the concept of Islamic banking. In the following discussion Islamic banking and interest free banking are used interchangeably.

\section{CONCEPT OF ISLAMIC BANKING}

Islamic banking is a banking practice as per the Islamic principles, prescribed in the 'Shariah' known as 'Fiqh al-Muamalat' (Islamic rules on transaction). The Islamic law prohibits 'riba' which means interest in Islamic discourse. It operates on the principle of sharing both profits and risks by the borrower as well as lender. The depositor, who unlike in the conventional banking system is risk-averse, is a provider of capital and equally shares the risks with the bank who lends his funds. . The basic principle of Islamic banking is the prohibition of Riba- (Usury - or interest) 


\section{Fiqure 1. Pillars of Islamic Finance}

1. Ban on interest: Interest must not be charged or paid on any financial transaction, as interest is deemed unlawful by
the Sharia.
2. Ban on speculation:Uncertainty in contractual terms and conditions is forbidden. However risk taking is allowed
where all the terms and conditions are clear and known all parties.
3. Ban on financing certain sectors deemed unlawful by sharia-such as weapons, pork, gambling, advertisement except
print media etc. are forbidden
4. The profit and Loss sharing principle: parties to the financial transaction must share the rewards and the risks
attatched to it.

An essential feature of an Islamic Sharia compliant product is Sharia scholar approval or Fatwa. Hence Islamic banks and conventional bank that invest some of their capital in Islamic finance through Islamic window have a relegious board or committee composed of Sharia sholars which examines proposed transactions and in case of Islamic bank reviews the overall activities of the bank for compliance with Sharia law.

\section{Scenario Of Islamic Banking Around The Globe}

Islamic banks have come into being since early 70s with the establishment of the first large Islamic banks namely Islamic Development Bank, Dubai Islamic Bank, Albaraka banking group but showed slow growth . In 1973 seven Arab nations banded together to form the Islamic Development Bank, which would function like the World Bank in promoting economic development, regional trade and Islamic financial markets but do so in a way that was acceptable to Islam. (The bank was launched in 1975 and now has more than 55 member states.) Demand for Sharia based services gathered momentum in th 1990's . This inerest was sparked due to the new geopolitical backdrop in the gulf and abundant liquidity flows from the recycling of oil dollars in the region. There are nearly 30 Islamic banks all over the world, from Africa, Europe to Asia and Australia, and are regulated even within the conventional banking system. The whole banking system in Iran has moved over to the Islamic system since the early $80 \mathrm{~s}$ and even Pakistan is Islamising its banking system. A number of European and American banks are now offering Islamic banking products, not only in Muslim countries, but also in developed markets, such as UK. The concept is also catching up in Malaysia and Dubai.

The presence of Islamic Banks in certain parts of the western world has been accompanied by the gradual development of the opinion of the local regulators in this regard. A few years ago the issue of Islamic bank was merely touched upon in public debate, and presented an appeal that was exotic to the regulators and financial institutions already existing in the financial market. Today the subject generates more interest and the market players are viewing it as an engine of growth from the perspective of gaining market share.

Of late there has been keen interest of the western world in tapping the liquidity of the Gulf countries. In U.K. for example the FSA(Financial Services Authority) has given license to the European Islamic Investment Bank a wholesale financial institution created expressly to channelise the massive amount of institutional and private liquidity in the gulf towards Shariah compliant asset classes of western markets. The FSA has taken this step with its sole objective of financial inclusion and has given green signals to its conventional banks to offer Sharia compliant services. HSBC through its Amanah brand and Lloyds TSB already offers Islamic financial services. It also intends to become the (FSA) key player in market intermediation for Sukuk ( Sharia compliant bond). Sukuks are the fastest growing segment of the Islamic finance market which has seen phenomenol growth in the past six years. In 2008 Moody's anticipate overall sukuk issuance to increase by around $30-35 \%$ per annum reaching US\$ 200 million by 2010 . Keeping in mind the opportunity offered by the Islamic banking FSA has also licensed a full fledged Islamic financial institution, the Islamic Bank of Britain in 2004. Germany has already issued a Sharia based security in 2004 and Japan also intends to tap the liquidity of the Gulf countries by issuing Sharia compliant financial securities. In U.S. the scope of Sharia based has been limited to trading of sharia compliant stocks through Dow Jones Islamic Index and Standards and Poor's Sharia Indices.

Islamic Financial Services Board (IFSB) which is a club of central banks that serves as a transnational regulatory body aiming to harmonize standards of prudential regulation applicable to Islamic banking estimates the world finance industry to be around US \$700 million(2008).

\section{Status Of Islamic Banking In India}

Although Islamic banking have been practiced in India since long (some belong to pre-partition days) it never caught the eye of the financial reformers. In India truly speaking there are no Islamic banks, but certain forms of Islamic financial Institutions exist which has been providing financial services on interest free basis. These are Financial Associations of Persons which are not registered under any provision of law, Interest-free Funds or Islamic Welfare Societies registered either under the Societies Act or the Trust Act, Islamic Cooperative Credit Societies registered with the registrar of cooperative societies, and Islamic investment 
companies registered under the Companies Act. The number of Islamic financial institutions operating in India are estimated to be around 300 with total demand deposits of around Rs. 800 million. With the growing awareness and increase in demand for interest free banking, Islamic banking in India started in a limited manner by certain Non-Banking Financial Companies. They are licensed under Non Banking Finance Companies Reserve Bank Directives 1997 RBI (Amendment) Act 1997, and operate on profit and loss based on Islamic principles and do not function under banking regulations. The Indian banks are goverened by the Banking Regulation Act 1949, Reserve Bank of India Act 1934, Negotiatiable Instruments Act and Co-Operative Society Act which is based on the premise of interest charge and does not allow interest free banking which is the main pillar of Islamic banking.

The study of TASIS (Taqwaa Advisory and Shariah Investment Solutions) on 'Muslim Financial Institutions in India (MFIs):Analysis and Scope of their Islamicity Under the Current Financial Reforms' conveys the increasing awareness and interest of Islamic funds in India. Based on their study of certain selected Islamic Financial Institutions for the period 1998-2002 it has been found that Deposits and Advances percentage are on continous increase. The amount of the total deposits of these selected institutions have increased from Rs. 246.36 million in 1998 to Rs. 476.54 million in 2002 whereas the advances has grown in 2002 to Rs. 148.68 million from Rs.88.1 million in 1998. The average annual growth in deposits have been found out to be around $18 \%$ whereas the average annual growth in advances are found out to be $14.04 \%$. This suggests that there is immense potential of Islamic banking in India

\section{Comparison of the Islamic Banking with the Conventional Banking Especially In Context Of The Indian Banking Sector.}

The call for Islamic banking in India necessitates its comparison with the conventional banking practices of India. This is important for creating a framework for co-existence of Islamic banking along side the conventional banking practices. The following account on the liability side are discussed below:

Current account : It is the only account where similarities can be drawn between Interest free banking and conventional banking practiced under the Banking Regulation Act. Current account deposits does not involve payment of interest to depositors.

Savings Account ( Al Wadiah) : Section 21 of the Banking Regulation Act requires payment of interest on such deposits where as in case of Islamic banking Savings deposit accounts operate in different ways. In some banks, the depositors allow the banks to use their money but they obtain a guarantee of getting the full amount back from the bank. Banks adopt several methods of inducing their clients to deposit with them, but no profit is promised. In others, savings accounts are treated as investment accounts but with less stringent conditions as to withdrawals and minimum balance. Capital is not guaranteed but the banks take care to invest money from such accounts in relatively risk-free short-term projects. As such lower profit rates are expected and that too only on a portion of the average minimum balance on the ground that a high level of reserves needs to be kept at all times to meet withdrawal demands.

Investment account (Mudarabah): Section 21 of the Banking Regulation Act disallows such products where the bank can invest the money in equity funds (in India, equity exposure is determined by a separate set of rules), and the client has complete freedom in the management. Where as under the Islamic banking laws Investment deposits are accepted for a fixed or unlimited period of time and the investors agree in advance to share the profit (or loss) in a given proportion with the bank. Capital is not guaranteed. Section 19(2) provides for restriction on any banking company holding shares in any company whether as pledgee, mortgagee or absolute owner. No bank can hold shares in any company, whether as pledge, mortgagee or absolute owner, of an amount exceeding 30\% of the paid-up share capital of that company or $30 \%$ of its own paid-up capital and reserves

Looking to the asset side the rules of the Banking regulaton Act that is in contrast to the principles of Islamic banking are discussed below :

Project Financing (Mudharabah or Musharakah) : Sections 5, 6 of the Banking Regulations Act indicate the forms of business a banking company can undertake, and does not allow any kind of profit-sharing and partnership contract the basis of Islamic banking. Wheres sharing of risk and loss is the fundamental principles if Islamic banking and principles of $\mathrm{Al}$ mudharabah or Musharakah are used for project financing. The former works in a manner used in the case of investment deposits. In this, bank provides the entire capital and the borrower, often an entrepreneur, provides the management services. The profit is shared accordingly to an agreed proportion while the loss is borne by the bank alone. Under the model of Musharakah, the bank shares the cost of project with the entrepreneur based on an agreed proportion basis and both parties have the right to 
participate in the management of the projects. The profit from the project is distributed according to an agreed ratio, which is not necessarily the same as the share in the cost.

Home finance (Ijarah) : In case of home finance the bank buys the asset and leases it to the customer for a rental fee which includes the cost of the house plus a profit margin. The bank owns the asset till the last instalment is paid. After payment of the last instalment the customer becomes the owner of the house. As against Islamic banking where the banks owns the asset and hold the title, Section 9 of the Banking Regulation Act 1949 prevents the bank from holding any sort of immovable property other than private use. According to the provisions of the Act it can acquire and hold and generally deal with any property or any right, title or interest in any such property which may form the security or part of the security for any loans or advances or which may be connected with any such security.

Other practices by the RBI (Reserve Bank of India) as a lender of last resort and regulator of the monetary measures which comes in the way of Islamic banking is that the commercial banks have to keep a part of their deposits with the RBI in form of cash for which the RBI prescribes the CRR (Cash Reserve Ratio) from time to time. The RBI pays interset on these deposits. The banks also have to meet the criteria of SLR (Statutory Liquidity Ratio) where it has to park certain percentage of their funds into central government securities and other approved securities on which it earns interest. This is in contravention to the principle of Islamic Banking which prohibits Interest.

\section{Initiatives Taken By The Government Towards Interest-Free Banking}

The various generations of financial sector reforms have brought the Indian economy in the race of being one of the top economies of the world. The objective of Inclusive growth through the financial sector apart from others, called for further generations of financial sector reforms and the Planning comission constituted a high powered committee headed by the former chief economist of International Monetary Fund Raghuram Rajan which submitted its report to the planning commission in September 2008. Three reasons have been cited by the Raghuram Rajan Committee report on Financial sector reforms:

1) to include more Indians in the growth process; (financial inclusion)

2) to foster growth itself; and

3) to improve financial stability, flexibility, and resilience and thus protect the economy against the kind of turbulence that has affected emerging markets in the past, and is affecting industrial countries today.

The Committee believes that it is important to improve the infrastructure for financial inclusion. Apart from raising various issues for improving financial infrastructure for inclusion, the committee also discussed interest -free banking an alternate form of banking based on Sharia.

According to the Committee report on Financial Sector Reforms,

'Certain faiths prohibit the use of financial instruments that pay interest. The non availability of interest-free banking products (where the return to the investor is tied to the bearing of risk, in accordance with the principles of that faith) results in some Indians, including those in the economically disadvantaged strata of society, not being able to access banking products and services due to reasons of faith. This non availability also denies India access to substantial sources of savings from other countries in the region.

While interest-free banking is provided in a limited manner through NBFCs and cooperatives, the Committee recommends that measures be taken to permit the delivery of interest-free finance on a larger scale, including through the banking system. This is in consonance with the objectives of inclusion and growth through innovation. The Committee believes that it would be possible, through appropriate measures, to create a framework for such products without any adverse systemic risk impact.'

The draft report of the Working Group which was constituted by Indian Banking Association (IBA) under the Chairmanship of Mr. M R Umarji, Chief Advisor (Legal), IBA to review the Banking Regulation Act, 1949 also discussed issues relating to competence of the commercial banks in India to undertake Islamic Banking. The report that was published by IBA in 2008 is of the view that,

'Since Islamic Banking is a totally new concept in the context of banking in India, the Group is of the view that its introduction needs to be preceded by a detailed study from various angles including the pros and cons of such introduction, and various other factors, such as banking in India being general and open to all irrespective of caste and creed, etc. Having so considered, if it is decided to introduce in India, sweeping amendments to Banking Regulation Act will have to be considered. The further issues will be whether the banks should have a separate window for Islamic banking or should undertake this activity by floating a subsidiary. It will be necessary to formulate separate regulations and guidelines for this purpose including the format of the balancesheet therefore since collection and payment of interest will not be permissible. It will also be necessary to examine the taxation aspects of Islamic banking and consider whether Income Tax Act will need any modification.' 


\section{The case for including Islamic Banking as an alternative banking in India.}

Althouh the Raghuram Rajan Committee has recomended steps to be taken to permit the delivery of interest-free finance on a larger scale, including through the banking system, it is yet to be seen how this will be carried forward by the market regulators . The conventional banking as practiced by the Indian banking sector in its present form does stand in the way of the principles of Islamic banking and introduction of interest free banking will require a lot of changes in the Banking Regulation Act as suggested by many experts. The advocacy of Islamic banking in India stands justified on the basis of the following ground:

a)Islamic banking operations could enable inclusive growth in India : Financial Inclusion is considered to be critical for achieving inclusive growth; which itself is required for ensuring overall sustainable growth in the country. The approach to Financial Inclusion in developing countries such as India is thus somewhat different from the developed countries. In the latter, the focus is on the relatively small share of population not having access to banks or the formal payments system whereas in India, the focus is on the majority who are excluded. One of the reasons cited for the deplorable conditions of the Muslims in the Sachar Committee Report on socioEconomic status of the largest minority segment in India has been low access to credit by the community. 'The financial exclusion of Muslims has far-reaching implications for their socio-economic and educational upliftment. Self-employment is the main source of income of Muslims. To empower Muslims economically, it is necessary to support self employed persons by ensuring a smooth flow of credit to them'. One reason which can be attributed for low participation of Muslims in the banking sector is the financial practices of the conventional banking which is entirely based on interest. The table below shows the minimal presence of the Muslim community in banking practices.

Muslims constitute the second largest religious group whose population was enumerated to be 138 million according to the 2001 census. The Sachar Committee report estimates that as of 2006 it must have crossed 150 Million people. Despite being a significant percentage of $13 \%$ (which forecasted might grow to $19 \%$ by 2040 ) the aggregate deposits with the Scheduled commercial banks remain to a low of $7.8 \%$. The estimated credit loss to Indian Muslims stands to be $27.3 \%$ of their deposits which amounts to a whopping RS. 64,770 crore. This calls for speeding up the creation of a framework for starting the interest free banking in a full fledged manner. This can lead to the inclusive growth of the country.

b)Solution for liquidity problem: India could not be insulated from the downturn in the global economic scenario. With the liberalized financial sector the impact of recession could be seen on the movements of funds. With the FII's (Financial Institutional Investors) pulling their money to adjust their liquidity solutions back home the capital market of India saw huge amount of loss. The government has been continuously easing out the interest rates for injecting growth in the economy. According to the CSO estimate regarding the GDP, it might be around $7.6 \%$ for the year 2008-09 which many of the research institutes feel is very optimistic looking at the global scenario. Global ECS Research at Goldman Sachs estimate the GDP growth rate to be around $6.7 \%$ for the first quarter of 2009. Global Financial Services firm Nomura has cut the GDP forecast to $5.8 \%$ for year 2012-13. To arrest this negative trend in growth the government will have to come up with lot of monetary changes which will have ramifications on the whole financial sector . Islamic Banking can be one of the instrumental force in addressing this type of issues. Islamic banking is based upon sharing of profit or loss which is near to the equity side. Opening of Islamic banks in India with amendments to the Banking Regulations Act regarding equity participation of banks can lead to the depth of the capital market and easy access of funds to the corporate houses.

"Equity based financing with the absence of interest earnings in any form drives domestic savings and real growth. Equity based financing through Isamic banking is set to rapidly increase the exposure of equity market and hence liquidity.”( G. Pvaithra, 2008)

c)Attracting foreign capital :The adoption of Islamc banking can also help the Indian economy in attracting investments from cash rich Middle East countries and muslim NRI's who would park their savings otherwise in other countries providing Islamic banking at an opportune time when India is becoming an attractive investment destination driving on its strong fundamentals. Realising its importance some of the private sector companies are viewing it as a mechanism for attracting capital. Five Indian companies, Reliance Industries, Infosys Technologies, Wipro, Tata Motors and Satyam Computer Services figure in the Standard \& Poor's BRIC Shariah Index, comprising of stocks from the four emerging countries - Brazil, Russia, India and China. The Shariah compliant constituents in the index represent the most liquid stocks trading on developed market exchanges, specifically the Hong Kong Stock Exchange, the London Stock Exchange, NASDAQ and NYSE.

d)Minimizing risk exposure of banks: Banks always have to bear the brunt of defaults simply because of neglect in credit analysis. Islamic banking follows strict norms of credit rating which to a great extent minimize 
the occurrence of bad debts. Under the models of Musharakah the bank shares the cost of project with the entrepreneur based on an agreed proportion basis and both parties have the right to participate in the management of the projects. The profit from the project is distributed according to an agreed ratio, which is not necessarily the same as the share in the cost. The important feature of both the parties participating in the management reduces the chance of loss as both are conscious in managing the funds and the entrepreneur cannot think of utilizing the funds in irresponsible manner.

\section{Issues In Introducing Islamic Banking}

The banking practices are governed by the Banking Regulations Act 1949, the principles of which are in contrast to the principle of Islamic banking. Introducing Islamic banking will require suitable amendments required for introducing banking practices based on Sharia laws.

The existing practices of Islamic financial institutions indicate the limitation of sound financial practices due to lack of professionaly trained personels in the area of Islamic banking. Confusion might arise because of different interpretations of sharia law by various groups. The introduction of Islamic banking would require a pro-active approach of preparing well trained professionals by providing rigorous training in the field of Sharia banking.

Creating awareness among lot of ignorant Muslims regarding the presence of Islamic banking in India will be required to get the benefit of economies of scale. An important point in introducing Islamic banking, will be the issue of deciding the beneficiaries of interest free banking. Will it be available to everybody or to only those who have registered themselves as willing to trade in Islamic banking.

\section{Suggested Models For Islamic Banking In India}

Model I : Bringing all the existing Islamic financial institutions under one governing body and standardising their practices and consolidation through mergers.

Model II : There can be Islamic windows in the already existing commercial banks which can act on the principles of Islamic finance. The government can set separate rules for these without changing existing laws for conventional banks $\mathrm{n}$ existence.

Model III: Following the examples of various countries who have opened full fledged Islamic banks for attracting investments from those segment of population who abstain from conventional banking due to religious inhibitions, India can also follow steps looking at the immense potential of Islamic banking in India. These banks can be governed by a separate segment of laws based on the Sharia, under the Banking Regulations Act, 1949.

These models in itself requires debate as to the ramification it will have on the entire financial market.

\section{Conclusion}

The Indian Financial Sector is forging ahead to meet its objective of financial inclusion as a part of broader principles of inclusive growth and Islamic banking is one of the solution towards financial inclusion. The stage for introduction of Islamic banking in India have been set, but it is a matter of time before it is given green signal. But introduction of Islamic banking without a solid framework will lead to chaos and conflicts. There for preparatory work is essential for including the Islamic banking in the mainstream Banking sector which at present lies in the domain of Non-Banking Financial Companies. This demands amendments in the banking laws that are governed by the Banking Regulations Act 1948 as amended from time to time. Introduction of Islamic banking will lead to inclusion of certain chunks of population who refrain from the mainstream banking due to their faith and they are a sizeable percentage from among the $13 \%$ (2001 Census) of Muslims which are forecasted to be $19 \%$ by 2040 .

\section{References}

[1] 'Financial Inclusion-The Indian Experience' By Usha Thorat, RBI Monthly Bulletin July 2007

[2] 'Islamic banking \& its Operations', Institute of Islamic Banking \& Insurance, ht tp://www.islamic-banking.com

[3] 'Muslim Financial Institutions in India (MFIs):Analysis and Scope of their Islamicity Under the Current Financial Reform' A T ASIS study, http://www.tasis.co.in

[4] 'Raghuram Rajan advocates introduction of Islamic banking.', The Financial Express, September 4, 2008

[5] 2007 Review and Outlook 2008 : Islamic Finance, Moody's Investor Service

[6] A Hundred Small Steps: Report of the committee on Financial Sector Reforms., GOI, Planning commission. Sage Publication (2009) http://www.planningcommission.gov.in/reports/genrep/report fr.htm

[7] Banking Regulation Act, 1949

[8] Directory of Islamic banks and financial institutions 2009

[9] Draft Report of the Working Group to review the Banking Regulation Act, 1949, Indian Banks' Association, May 2008

[10] G. Pavithra, (2008) Dissertation on 'Islamic Banking in India: Status, Prospects and Recommendations

[11] http://www.indianmuslims

[12] Islamic Banks in India: issues and constraints., Prof. M.H. Jawahirullah.

[13] Islamic Finance Outlook 2008. Islamic Financial services Board and Standards \& Poors. 
[14] Islamic Finance:A Growing Industry by Dr. Salina HJ Kassim and Dr. M. Shabri Abd. Majid, International Islamic University Malaysia.(2009) http://www.islamonline.net

[15] Islamic financial institutions awards 2008., Platt, Gordon. Global finance publication, June1, 2008

[16] Khatkhatay,M.H. [2003], "Islamic Banking in IndianContext," in Islamic Banking in India: Scopes \& Challenges, ed. JavedAhmad Khan (NewDelhi: Institute of Objective Studies)

[17] M.Y. Khan (2000) 'Banking regulations and Islamic banks In India : status and issues'.,. International Journal of Islamic Financial Services Vol. 2 No.4

[18] Omar Khan (2004) 'A proposed introduction of Islamic Banks in India'.,. International Journal of Islamic Financial Services Vol. 5 No.4

[19] Sachar Committee Report, 2006

[20] Scope of Islamic Finance in India, http://investindia.kotak.com/media/islamic-finance.html

[21] The World Islamic Banking Competitiveness Report 2011/12 